\title{
Infected auricular keloid secondary to attempted self- amputation of a gauge earring
}

\author{
Devin N Reddy, ${ }^{1}$ Nicholas Armando Rossi $10,{ }^{2}$ Jason F Ohlstein, ${ }^{3}$ Orly Coblens ${ }^{2}$
}

\begin{abstract}
${ }^{1}$ School of Medicine, University of Texas Medical Branch, Galveston, Texas, USA ${ }^{2}$ Otolaryngology - Head and Neck Surgery, University of Texas Medical Branch, Galveston, Texas, USA ${ }^{3}$ Otolaryngology - Head and Neck Surgery, St. Luke's University Hospital, Bethlehem, Pennsylvania, USA
\end{abstract}

\section{Correspondence to} Dr Nicholas Armando Rossi; nicholas.armando.rossi@gmail. com

Accepted 20 September 2021

\section{DESCRIPTION}

A male inmate in his 20s presented to the otolaryngology clinic for evaluation of left ear swelling that began shortly after placement of gauge earrings in his bilateral ear lobes 2 years ago. About 1 month after insertion, his left ear became infected. $\mathrm{He}$ then tied two strings around the infected ear lobe in hopes that the ear lobe itself would subsequently detach. After each string was placed by the patient, two necrotic lobular keloid scars began to appear with surrounding purulent drainage, prompting him to seek medical attention. The patient reported minimal pain, and about 1 week of antibiotics was trialled without any improvement in his symptoms.

Physical examination showed a complex, pedunculated, bilobed keloid hanging from the inferior edge of the left auricular lobule (figure 1). Two

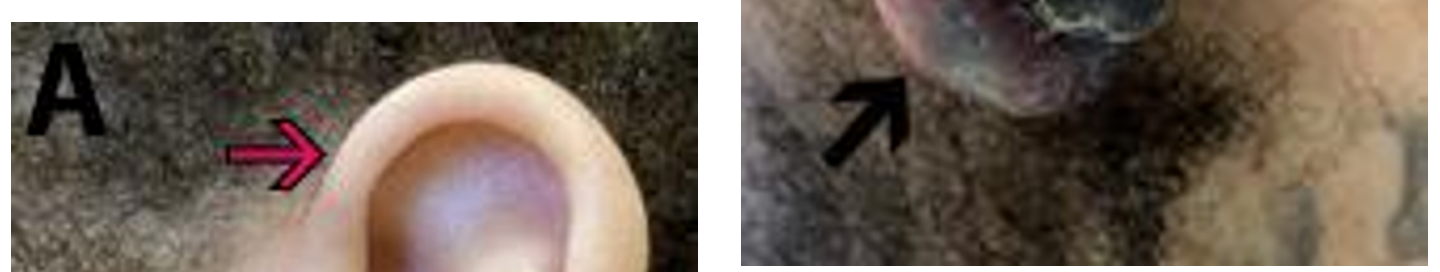

Figure 2 Inferior view of the patient's multinodular sessile-type keloid scar (black arrows). Note the blackened, necrotic tissue at the inferior portion of the scar and the self-applied string (orange arrow). Ear anatomy: helix (red arrow).

separate lobulated masses were seen, tied off with the string at their base. There was partial necrosis of the inferior aspect, moderate purulent drainage, and the keloid was insensate (figure 2). The string foreign bodies were removed in clinic, and the decision was made to surgically excise the keloid mass with conscious sedation to maximise patient comfort and cosmetic outcome. The keloids were each grasped and cut from the lobule with curved iris scissors. Two distinct tissue defects remained on both the anterior and posterior aspects of the lobule. These were reapproximated with 5-0 fast absorbing gut suture, making sure not to overtighten suture and thus distort the integrity of the lobule. The patient was discharged with a 2-week course of ciprofloxacin. Unfortunately, the patient was not brought to his postoperative appointment, and he has been lost to follow-up since.

Ear gauging begins similarly to the more common ear piercing with a $1 \mathrm{~mm}$ hole created in the auricular lobule, followed by expansion with increasing sizes of an ear plug. ${ }^{1}$ Keloids are the atypical 
proliferation of scar tissue at the location of cutaneous disruption and injury, characteristically growing beyond the original confines of the scar without regression. Keloid formation after earring placement may be predisposed by extrinsic trauma to the region, allergies to earring materials, infection due to non-sterile piercing conditions or otherwise, mechanical force from contact with a pillow during sleep, and the weight of the earring. ${ }^{2-5}$ It is unclear of the predisposing history in this patient's case of keloid scarring; however, poor healthcare-literacy as evidenced by attempted self-amputation of the scar likely contributed to the extent of keloid formation and necrosis seen. Additionally, incarcerated and formerly incarcerated populations may present at later disease stages and often have lower levels of health literacy than the free world population. ${ }^{6}$

The patient's multinodular sessile-type keloid was treated with radical keloidectomy, involving minimal amount of soft tissue to curtail further trauma. Closure of the injury along

\section{Learning points}

- This patient's keloid scarring was likely due to inflammatory complications of ear gauging, not uncommonly seen after placement of ear piercings or earrings.

- Incarcerated populations have additional barriers to medical care compared with free world populations; these barriers should be taken into consideration when weighing appropriate treatment options.

- Excision of the mass is a common treatment for keloid scarring, ideally involving minimal amounts of soft tissue and tension across the wound closure to reduce likelihood of keloid recurrence. relaxed skin tension lines, skin grafts and targeting postoperative inflammation medically are common techniques used to minimise wound tension and reduce further scarring. Other treatment options may include occlusive dressings, radiation, laser therapy, cryotherapy and pharmacotherapy (eg, corticosteroids, 5-fluorouracil, imiquimod). ${ }^{7}$

Contributors This manuscript is approved by all authors and has not been previously reported nor submitted for report in any other publication. Author contributions include drafting and editing of manuscript by DNR, NAR, JFO and OC. Concept, guidance and review of manuscript was completed by OC.

Funding The authors have not declared a specific grant for this research from any funding agency in the public, commercial or not-for-profit sectors.

Competing interests None declared.

Patient consent for publication Consent obtained directly from patient(s).

Provenance and peer review Not commissioned; externally peer reviewed.

ORCID ID

Nicholas Armando Rossi http://orcid.org/0000-0002-7105-2196

\section{REFERENCES}

1 Diepenbrock RM, Fries CJ. The gauged earlobe: a review of current treatment methods and presentation of a new technique. Am J Cosmet Surg 2015;32:233-7.

2 Breuner CC, Levine DA, COMMITTEE ON ADOLESCENCE. Adolescent and young adult tattooing, piercing, and scarification. Pediatrics 2017;140:e20163494.

3 Hochman B, Isoldi FC, Silveira TS. Does ear keloid formation depend on the type of earrings or piercing jewellery?: Earrings and keloid formation. Australas J Dermatol 2015;56:e77-9.

$4 \mathrm{Kim} \mathrm{HD}$, Chu SC, Hwang SM, et al. Clinical analysis of lobular keloid after ear piercing. Arch Craniofac Surg 2016;17:5-8.

5 Ogawa R. Keloid and hypertrophic scars are the result of chronic inflammation in the reticular dermis. Int J Mol Sci 2017;18:606.

6 Hadden KB, Puglisi L, Prince L, et al. Health literacy among a formerly incarcerated population using data from the transitions clinic network. J Urban Health 2018;95:547-55.

7 Thornton NJ, Garcia BA, Hoyer P, et al. Keloid scars: an updated review of combination therapies. Cureus 2021;13:e12999.

Copyright 2021 BMJ Publishing Group. All rights reserved. For permission to reuse any of this content visit

https://www.bmj.com/company/products-services/rights-and-licensing/permissions/

BMJ Case Report Fellows may re-use this article for personal use and teaching without any further permission.

Become a Fellow of BMJ Case Reports today and you can:

- Submit as many cases as you like

- Enjoy fast sympathetic peer review and rapid publication of accepted articles

- Access all the published articles

- Re-use any of the published material for personal use and teaching without further permission

Customer Service

If you have any further queries about your subscription, please contact our customer services team on +44 (0) 2071111105 or via email at support@bmj.com.

Visit casereports.bmj.com for more articles like this and to become a Fellow 